\title{
Doktora Öğrencilerinin Doktora Eğitimi ve Öğretim Üyelerine Yönelik Metaforik Algıları
}

\section{Phd Students' Metaphoric Perceptions on Doctorate Education and Instructors}

\author{
ibrahim LiMON ${ }^{*} \quad$ Mehmet DURNALI ${ }^{\star \star}$
}

Öz. Bu çalışmanın amacı, doktora öğrencilerinin 'doktora 'eğitimi' ve 'öğretim üyelerine' yönelik algılarını metaforlar aracılığı ile belirlemektir. Çalışma grubu farklı üniversite ve bölümlerde doktora eğitimine aktif olarak devam eden 63 doktora öğrencisinden oluşmaktadır. Araştırmanın çalışma grubu amaçlı örnekleme yöntemlerinden ölçüt örnekleme yöntemi ile seçilmiştir. Araştırma nitel araştırma yöntemlerinden biri olan olgubilim deseninde kurgulanmış; elde edilen veri içerik analizi yöntemi ile analiz edilmiştir. Veri toplama aracı olarak, araştırmacılar tarafından geliştirilen yarı yapılandırılmış bir metafor formu kullanılmıştır. Yapılan analiz sonucunda, katılımcıların doktora eğitimine yönelik 52 farklı toplam 56 metafor ürettikleri görülmüştür. Bu metaforlar gerekçelerin niteliklerine göre kategorilere ayrıldığında; 29 metaforun olumlu; 25 metaforun olumsuz ve 2 metaforun ise yansız algıları yansıttığı görülmektedir. Öğretim üyelerine yönelik 43 farklı toplam 58 metafor ortaya konmuştur. Bu metaforlar gerekçelerin niteliklerine göre kategorilere ayrıldığında; 38 metaforun olumlu algıları, 12 metaforun olumsuz algıları, 1 metaforun yansız algıları yansıttığı; 7 metaforun ise iki yönlü olduğu değerlendirilmiştir.

Anahtar Kelimeler: Doktora, öğretim üyesi, metafor, algı.

\begin{abstract}
The aim of this study is to determine Phd students' perceptions on 'doctorate education' and 'instructors' by means of metaphors. The study group consists of 63 students actively attending their doctorate education at various departments of some universities in Turkey. This group was chosen using criterion sampling method which is one of the purposive sampling methods. The current study was designed as a phenomenological study one of qualitative research methods. The data was analyzed through content analysis. To collect the data a semi structured form which was developed by the researchers was utilized. The results showed that participants totally produced 56 metaphors and 52 of them were different. When the metaphors were grouped based on the reasons put forward; 29 of the metaphors reflected positive perceptions, 25 of them reflected negative perceptions and two of them reflected neutral perceptions. Participants produced 58 metaphors for instructors and 43 of them were different. When these metaphors were grouped based on the reasons put forward, 38 of them reflected positive perceptions, 12 of them negative perceptions and one of them neutral perceptions. As for 7 metaphors, they reflected positive and negative perceptions simultaneously.
\end{abstract}

Keywords: Doctorate, instructor, metaphor, perception.

Toplumsal Mesaj.
Bu çalışma ile doktora
öğrencilerinin almış oldukları
eğitim ve bu eğitimin
yürütücüsü olan öğretim
üyelerine yönelik algıları
benzetmelerden
yararlanılarak
konmuştur. Buna göre,
doktora öğrencilerinin yarıya
yakını eğitimin kendisi
açısından olumsuz algılara
sahiptir. Öğretim üyelerine
yönelik algıları ise nispeten
daha olumludur.

\section{Public Interest Statement.}

This study aims to determine doctorate students' perceptions of the education they get and their instructors. In line with this aim, metaphors were employed. Findings show that nearly half of the students have negative perceptions of doctorate education. On the other hand, they have a relatively positive perceptions of their instructors.

\footnotetext{
* Doktora Öğrencisi, Abant İzzet Baysal Üniversitesi Eğitim Bilimleri Enstitüsü, Eğitim Yönetimi ve Denetimi Bilim Dalı, ibomon@gmail.com

** Doktora Öğrencisi, Hacettepe Üniversitesi Eğitim Bilimleri Enstitüsü, Eğitim Yönetimi Bilim Dalı, durnali@gmail.com 


\section{GíRiş}

Günümüzde lisansüstü eğitim, özellikle de doktora eğitimi, uluslararası toplumda çok büyük önem atfedilen bir konu haline gelmiştir. Küreselleşmenin etkisi ve Bologna Süreci ile birlikte yaşanan gelişmeler, ülkelerin ihtiyaç duyduğu nitelikli insan gücünü yetiştirecek bir sistemin gerekliliğini daha belirgin hale getirmiştir. Söz konusu insan gücünün ülkelerini bilgi toplumları arasında ve ekonomik anlamda etkili bir konuma taşımada en üst düzeyde rol oynaması beklenmektedir (Eggins, 2008). Bu amaçlar doğrultusunda üniversiteler lisansüstü programlar düzenlemektedir (Karakütük, 1989). Düzenlenen bu programlar sayesinde öğrencilere belirli özellikler kazandırarak toplumun bilimsel anlamda gereksinimlerinin karşılanması hedeflenmektedir (Aslan, 2010). Ayrıca, lisansüstü eğitim bireylerin mesleki ve kişisel gelişimlerine önemli katkılar sunan bir süreç olarak da nitelendirilebilir (Güleç ve Güleç-Aslan, 2013).

Lisansüstü Eğitim ve Öğretim Yönetmeliğinde yüksek lisans, doktora ve sanatta yeterlilik olmak üzere üç farklı programdan söz edilmektedir (Madde 1). Doktora programları da bu noktada en üst dereceyi ifade eder (Balcı, 2013). Doktora programlarından mezun olan öğrenciler bir kurumun en iyi öğrencilerini temsil eder. Ayrıca, bu öğrenciler yarının dünya liderleri olma potansiyeli en yüksek olanlardır. Doktora programları öğrencileri akademik veya araştırma kariyerine hazırlamanın yanında daha birçok sektöre (iş, sanayi, hizmet sektörü ve kamu) kaynak oluşturmaktadır. Ayrıca, öğrenciler bu programlar sayesinde uluslararası ortamlara uyum sağlayacak nitelikleri kazanır (Bernstein, Evans, Fyffe, Halai, Hall, Jensen, Marsh ve Ortega, 2014). Lisansüstü Eğitim ve Öğretim Yönetmeliğinde ise doktora programının amacı öğrenciye bağımsız araştırma yapma, bilimsel problemleri, verileri geniş ve derin bir bakış açısı ile irdeleyerek yorum yapma, analiz etme ve yeni sentezlere ulaşmak için gerekli becerileri kazandırma olarak ifade edilmektedir (Madde 15). Güner'e (2006) göre doktora eğitiminin öncelikli amacı alanında yetkin, güvenilir, bağımsız araştırma yürütebilen, bilimsel bakış açısı kazanmış bilim insanları yetiştirmektir. Doktora eğitimi sonunda bireylerin bir araştırma problemini çözerek anlamlı bir sonuca ulaşmış ve bilimsel gelişmeye kayda değer bir katkı sunmuş olmaları gerekmektedir.

Bernstein ve diğerleri (2014) küresel anlamda yaptıkları değerlendirmede doktora programlarından beklentinin üç ana başlık altında toplanabileceğini belirtmektedir. Bunlar;

- Mevcut bilgiye orijinal araştırmalar yoluyla katkıda bulunması,

- Mezunların alanlarında oldukça zengin bir bilgi birikimine sahip olması,

- Transfer edilebilir beceri ve yeterlikleri kapsaması.

Doktora programlarının bahsi geçen amaçları gerçekleştirebilmesi belirli standartları karşılamalarına bağlıdır. Bu bağlamda, YÖK 2015 yılında üniversitelerde yüksek lisans ve doktora programı açma ölçütlerini güncellemiştir (YÖK, 2015). Yeni ölçütlere göre doktora programlarında asgari öğretim üyesi sayısı beşten altıya çıkarılmış; bir yabancı uyruklu öğretim üyesi bu rakama dâhil edilmiş; doktora programında yer alacak ve doktora tezi yürütecek öğretim üyelerinin belirli bir deneyime sahip olması öngörülmüş; tez danışmanlığı için üst sınır getirilmiş ve tüm üniversitelerde tez savunmasından önce öğrenciden intihal raporu talep edilmesi kuralı benimsenmiştir. Yapılan bu düzenleme doktora ve yüksek lisans programlarında kalitenin artırıması için önemli bir adım olarak değerlendirilebilir. Öte yandan, Eggins (2008) doktora programlarında kalitenin artırılması ve amaçlanan hedeflerin gerçekleştirilebilmesi için bir dizi önerilerde bulunmuştur. Bu öneriler ise şu şekilde özetlenebilir;

- Lisansüstü eğitimin gelişimi ve yaygınlaşması, üniversitelerin içinde bulunduğu ortamın siyasi ve ekonomik açıdan istikrarlı olmasına bağlıdır. Bu yüzden, öncelikle siyasi ve ekonomik istikrarın sağlanması gerekir.

- Hükümetler lisansüstü eğitim sektörüne daha fazla yatırım yapmalıdır.

- Lisansüstü araştırmaların artması için hükümet ve farklı sektörler, yapılan araştırmalara sürekli destek sağlamalıdır.

- Lisansüstü eğitim konusunda hükümetlerin çeşitli politikalar geliştirmesi gerekir. 
- Lisansüstü programların değerlendirilmesi ve denetlenmesine önem verilmelidir.

- Kalitenin artırılması için hükümet ve/veya üniversitelerce çeşitli düzenlemeler yapılmalıdır.

- Doktora programlarına öğrenci seçerken ve bu öğrencilere danışman atanırken kurumsal düzeyde bir titizlik sergilenmelidir.

- Akademik personelin doktora programlarını ve tezlerini yürütecek yeterli bilgiye sahip olması gerekir.

- Akademik personel uluslararası dergilerde yayın yapmaya ve işbirlikçi uluslararası araştırmalara katılmaya teşvik edilmelidir.

- Üniversitelere akademik personel atanırken doktora danışmanlığı yürütebilecek uzmanlık ve zamana sahip kişiler seçilmelidir.

Bütün bunların yanında, Şen (2013) de verimli, etkin, yetkin, uluslararası seviyelere ulaşabilen ve hatta oraları geçebilen doktora çalışmalarının yapılabilmesi için birtakım öneriler sunmuştur. Buna göre, doktora programlarında özellikle alanın felsefesine ve mantık ilkelerine odaklanılmalı, iyi bir bilim insanı öncelikle kendi anadiline hâkim olmalı, süreç içerisinde öğrenci sadece danışmanı ile değil diğer paydaşlarla da işbirliği içerisine girmelidir.

YÖK 2016-2017 öğretim yılı istatistiklerine göre Türkiye'de faaliyet gösteren üniversitelerin sayısı 183'e ulaşmıştır. Söz konusu sayısal artış üniversitelerin ihtiyaç duyduğu akademisyen ihtiyacını da artırmıştır. Bu ihtiyaç ise yukarıda da bahsedildiği gibi doktora programları aracılığı ile yetiştirilen akademisyenler ile karşılanmaktadır. Tablo 1'de son dört yılda üniversitelerde herhangi bir doktora programına kayıtlı öğrenci sayıları sunulmaktadır.

Tablo 1. Doktora programlarına kayıtlı öğrenci sayıları

\begin{tabular}{cccc}
\hline Yll & Kadın & Erkek & Toplam \\
\hline $2016-2017$ & 53600 & 37667 & 91267 \\
$2015-2016$ & 35072 & 50392 & 86094 \\
$2014-2015$ & 32688 & 45535 & 78223 \\
$2013-2014$ & 28890 & 38267 & 67157 \\
\hline
\end{tabular}

*https://istatistik.yok.gov.tr/ adresinden 22.11.2016 tarihinde alınmıştır.

Tablo 1'den de anlaşılacağı üzere, son üç yılda doktora programlarına kayıtlı öğrenci sayısı dikkate değer bir şekilde artış göstermiştir. Öğrenci sayısındaki bu artışa paralel olarak genelde lisansüstü eğitim ve özelde doktora eğitimine yönelik araştırmalarda da nicel bir artış gözlenmektedir ( Bozpolat, 2016; Aslan ve Karagül, 2016; Çoruk, Çağatay ve Öztürk, 2016; Gürgan Öztürk ve Dinç, 2016; Şahin, Demir ve Arcagök, 2015; Aydoğmuş, 2015; Hark Söylemez, Dokumacı Sütçü ve Sütçü, 2014; Şen, 2013; Özmen ve Aydın Güç, 2013; Güleç ve Güleç Aslan, 2013; İpek Akbulut, Şahin ve Çepni, 2013; Balcı, 2013; Alabaş, 2012; Şaşmaz Ören, Yılmaz ve Güçlü, 2012; Karaman ve Bakırcı, 2010). Ancak, yapılan bu çalışmaların daha çok lisansüstü eğitimin sorunlarına ve söz konusu sorunlara yönelik çözüm önerilerine odaklandığı göze çarpmaktadır.

Joyner, Fuller, Holzweiss, Henderson ve Young (2014) lisansüstü eğitim bağlamında ele alındı̆̆ında öğrenci-öğretim üyesi arasındaki ilişkinin daha karmaşık bir yapıya büründüğünü ileri sürmekte; lisansüstü öğrencilerin gündelik yaşantıdaki sorumlulukları ve muhtemelen bir iş sahibi olmaları gibi sebeplerle daha fazla yıprandıkları ve bunun da öğretim üyeleri ile olan ilişkilerine yansıdığını değerlendirmektedir. Öte yandan, öğretim üyeleri açısından da birtakım zorluklardan söz edilebilir. Bøgelund (2015) yükseköğretimde bazı maddi kısıtlamalar, daha yüksek düzeyde bir hesap verebilirlik ve öğrenciler arasında gittikçe artan rekabetin sonucu olarak kültürel bir değişim yaşandığını belirtmektedir. Tüm bunlar ise akademik personelin çalışma koşullarını ve üniversitelerde bilgi üretimini büyük ölçüde etkilemiştir. Doktora eğitimi de aynı süreçten ayrı tutulamaz.

Golde ve Dore (2001) doktora eğitimini öğrencilerin gözüyle değerlendirmenin farklı bir bakış açısı sunacağını; öğrenci deneyimlerinin sistemin işlevlerini ne derece yerine getirdiğini ve hangi noktalarda aksaklıklar olduğunu belirlemede önemli bir araç olduğunu öne sürmektedir. Aynı bakış 
açısının öğretim üyeleri için de geçerli olduğu söylenebilir. Bu doğrultuda mevcut araştırma doktora öğrencilerinin doktora eğitimi ve öğretim üyelerine yönelik algılarını metaforlar aracılığı ile belirlemeyi amaçlamıştır. Son dönemde metafor çalışmalarının özellikle de eğitim alanında sıklıkla kullanılmaya başladığı görülmektedir (Bozpolat, 2016; Tulunay Ateş, 2016; Tiryaki ve Demir, 2016; Ekici, 2016; Kahyaoğlu ve Kırıktaş, 2016; Şahin ve Kaya, 2016; Uslu, Kocakülah ve Gül, 2016; Çelikkaya, Yakar ve Şarlayan, 2016; Kasapoğlu, 2016; Tünkler, Tarman ve Güven, 2016; Yalçın, Aydoğdu Özoğlu ve Dönmez, 2016; Meral, Küçük ve Gedik, 2015; Bahar-Güner, Tunca, Alkın-Şahin ve Oğuz, 2015; Ogurlu, Öpengin ve Hızlı, 2015; Yalçın Wells, 2015). Metafor sosyal bir gerçeği ifade etmede kullanılan dilsel araçtır (Döş ve Töremen, 2009). Bir başka tanımda ise metaforun anlaşılması zor konularda bireylere anlayış kazandırma özelliğinden bahsedilmektedir (Renz, 2009). Metafor kavramların birbirine benzerliğinden faydalanan benzetme sanatı olarak da ifade edilebilir (Yılmaz, 2011). Döş (2011) metaforların güçlü anlatım ve ifade yeteneğine sahip olduğunu ve anlatılmak isteneni kısaca ve kolaylıkla ifade edebildiğini belirtmektedir. Metaforlar hem dinleyici hem de konuşmacı açısından gerçekliği sıkıcılıktan kurtarır. Hedef kitlenin daha kolay anlayabileceği ve inanabileceği ifadeler ile hedef kitleye yeni bir düşünme biçimi sunabilmektedir (Kendall ve Kendall, 1993). Öte yandan, metaforlar bireylerin algılarını ortaya koymanın etkili bir yöntemidir (Yalçın ve diğerleri, 2016). Sıralanan bu özelliklerinden dolayı doktora öğrencilerinin doktora eğitimi ve öğretim üyelerine yönelik algılarını ortaya çıkarmak için metaforlardan yararlanmanın etkili bir yöntem olacağı düşünülmüştür.

\subsection{Amaç}

Bu çalışmanın amacı doktora öğrencilerinin doktora eğitimi ve söz konusu eğitimin en önemli yapı taşlarından olan öğretim üyelerine yönelik algılarının niteliğini metaforlar aracılığı ile belirlemektir.

\section{YÖNTEM}

Bu çalışma nitel araştırma desenlerinden olgubilim (fenomenoloji) yaklaşımında tasarlanmıştır. Olgubilim bireylerin bir olgu veya deneyime yükledikleri anlam veya bu yöndeki algılarını ortaya koymayı hedefler. Olgubilimde amaç bir olayı katılımcıların bakış açısından tanımlamak veya anlamaktır. Bu yaklaşımı diğer nitel yaklaşımlardan ayıran özellik öznel deneyimlerin araştırmanın merkezinde olmasıdır (Mertens, 2010). Araştırma kapsamında ele alınan olgular ise doktora eğitimi ve öğretim üyeleridir.

\section{1 Çalışma Grubu}

Araştırmanın çalışma grubu farklı üniversitelerde doktora eğitimine devam eden 63 öğrenciden oluşmaktadır. Araştırma grubu amaçlı örnekleme yöntemlerinden ölçüt örnekleme yöntemi ile belirlenmiştir. Bu örnekleme yönteminde temel anlayış önceden belirlenmiş bir dizi ölçütü karşılayan durumların örnekleme dâhil edilmesidir. Burada sözü edilen ölçüt ya da ölçütler araştırmacı tarafından belirlenebilir (Yıldırım ve Şimşek, 2016). Bu çalışmada ölçüt ise katııımcıların doktora ders, yeterlilik veya tez dönemine aktif olarak devam ediyor olmalarıdır.

Katılımcıların \%51'i erkek ( $f=32$ ); \%49'u ise kadındır ( $f=31$ ). Öte yandan; \%48'i ders döneminde $(f=30) ; \% 16$ 'sı yeterliliğe hazırlık döneminde $(f=10) ; \% 36$ 'sı ise tez dönemindedir $(f=23)$. Katılımcıların $\% 48$ 'i eğitim yönetimi ( $f=30) ; \% 14$ 'i endüstri mühendisliği $(f=9) ; \% 5^{\prime} i$ işletme $(f=3) ; \% 3 ' u ̈$ matematik eğitimi ( $f=2)$; $\% 3$ 'ü bilişim sistemleri $(f=2)$ ve $\% 27$ 'sı diğer bölümlerde $(f=17)$ eğitim almaktadır. Katılımcılar toplamda 16 farklı bölüme kayıtlıdır. Medeni durum ele alındığında katıımcıların \%60' bekâr ( $f=38), \% 38$ 'si evli ( $f=24)$ ve \%2'si diğer $(f=1)$ olduğu anlaşılmaktadır. Yaş açısından ele alındığında ise; katıımcıların \%42'si 25-30 yaş aralı̆ıında ( $f=26), \% 37$ 'si 31-35 yaş aralığında $(f=23)$ ve son olarak \%22'si 36 ve üzeri ( $f=14$ ) bir yaşa sahiptir.

\subsection{Veri Toplama Yöntemi}

Araştırma dahilinde veri yarı yapılandııılmış bir form aracılığı ile toplanmıştır. Kullanılan veri toplama aracı iki bölümden oluşmaktadır. Birinci bölümde katılımcıların demografik özelliklerini belirlemeye yönelik sorular yer almaktadır. İkinci bölümde ise 'doktora eğitimi' ve 'öğretim 
üyelerine' yönelik algılarını ortaya koymayı hedefleyen yarı yapılandırılmış iki ifade yer almaktadır. Söz konusu ifadeler aşağıdaki gibidir.

"Doktora eğitimi. gibidir çünkü.

"Programdaki öğretim üyeleri. .gibidir çünkü.

\subsection{Verilerin Analizi}

Mertens (2010) nitel araştırmalarda veri analizinin üç aşamalı olarak gerçekleştirilebileceğini belirtmektedir. Birinci aşama verilerin analiz için hazırlanması, ikinci aşama verilerin incelenmesi ve üçüncü aşama ise verilerin indirgenmesidir. Bu araştırma bağlamında birinci aşamada, metaforlar ve metaforlara ilişkin gerekçeler tablolara işlenmiştir. ikinci aşamada ise metaforlar ve gerekçeleri dikkatlice incelenmiş ve öncelikle metafor niteliği taşımayan ifadeler çıkartılmıştır. Daha sonra ifade metafor niteliği taşısa bile metafor ile gerekçe arasında tutarsızlık olduğunda da ifadeler araştırma dışında tutulmuştur. Üçüncü aşamada verilerin indirgenmesinde içerik analizinden faydalanılarak metaforlar gerekçelerden yola çıkılarak sınıflandırılmıştır. Rugg ve Petre (2007) içerik analizinde amacın araştırma konusu metinde ne söylendiği, nasıl söylendiği ve ne kadar sıklıkla söylendiğinin ortaya çıkarılmasıdır. Bu bağlamda tablolarda metaforların frekanslarına ve her kategoriye örneklere yer verilmiştir.

\subsection{Geçerlik ve Güvenirlik}

Araştırmada geçerliliği sağlamak için veriler ayrıntılı olarak ele alınmış, veri analizi süreci ayrıntıı olarak anlatılmış ve doğrudan alıntılar yapılmıştır (Yıldırım ve Şimşek, 2016).

Araştırmada güvenirliği sağlamak amacıyla ise oluşturulan kategoriler bağlamında araştırmacılar arasında görüş birliği aranmıştır. Bu amaçla Miles ve Huberman (1994) tarafından önerilen güvenirlik formülü kullanılmıştır. Buna göre araştırmacılar arasındaki görüş birliğinin \%70'in üzerinde çıkması, güvenirliğin sağlandığına işaret etmektedir.

\section{BULGULAR}

Tablo 2. Doktora eğitimine ilişkin metaforlar

\begin{tabular}{|c|c|c|}
\hline \multicolumn{3}{|c|}{ Metaforlar } \\
\hline güneş (2) & ilaç & buzdağı \\
\hline tünel (2) & istediğim yere varan yokuş & reçete \\
\hline hayat (2) & ek iş yapmak & nereye çıkacağı belirsiz bir yol \\
\hline merdiven (2) & Uludağ & arena \\
\hline boşa kürek çekmek & inşa edilmesi gereken bina & geleceğim \\
\hline dipsiz kuyu & tuzlu kahve & yeni maceralara yelken açmak \\
\hline tropik orman & bol bonuslu oyun & serüven \\
\hline amelelik & dikenli bir yol & omuzdaki rütbe \\
\hline sindirim & Mario oyunu & en sevdiğim tatlı \\
\hline yeni bir dünyayı keşif & kök & maden arama \\
\hline çileli bir yolculuk & uzun bir seyahate çıkan gezgin & estetik operasyon \\
\hline ayağın altına yapışan sakız & bilgisayar & son rötuş \\
\hline gökyüzü & vitamin & kendini gerçekleştirmek \\
\hline zorlu bir maraton & kaktüs & örümcek ağı \\
\hline basamak & anahtar & okyanus \\
\hline kütüphane & akarsu & geleceğe açılan bir yol \\
\hline zorlu ama vazgeçilmez bir yol & piknik & \\
\hline pişme süreci & merdiven çıkmak & \\
\hline
\end{tabular}

Tablo 2'de katılımcıların doktora eğitimine yönelik ortaya koydukları metaforlar sunulmaktadır. Buna göre katılımcılar 52'si farklı toplam 56 metafor üretmiştir. Yedi katılımcının ise doktora eğitimine yönelik ya metafor üretmediği ya da ortaya konan ifadenin metafor niteliği taşımadığı görülmüştür. Bu nedenle, bu ifadeler tabloda yer almamaktadır. Öte yandan, sadece güneş $(f=2)$, 
tünel $(f=2)$, hayat $(f=2)$ ve merdiven $(f=2)$ metaforlarının tekrar ettiği göz önünde tutulduğunda; katıımcıların algılarının oldukça çeşitlilik arz ettiği söylenebilir. Aşağıda katılımcıların ifadelerinden örnekler yer almaktadır.

Örnek ifadeler:

"Doktora eğitimi vitamin gibidir. Çünkü bana enerji verir."(K1)

"Doktora eğitimi estetik operasyon gibidir. Çünkü beynimizi, zihnimizi, zekamızı, ruhumuzu güzelleştirmenin tek yolu tozlu raflar arasında astıma aşık olacak kadar operasyonda/ameliyatta kalmaktır." (K3)

"Doktora eğitimi Uludağ gibidir çünkü başarmak için önünüzde çok uzun ve belirsiz bir yol vardır." (K14) "Doktora eğitimi arena gibidir çünkü sürekli arenadaki gladyatörler gibi hayatta kalma mücadelesi veriyorum." (K24)

"Doktora eğitimi maden arama gibidir çünkü birçok veri arasından araştırarak, zorlayarak doğru ve geçerli veriyi bulup bu veriyi bilgiye dönüştürmek anlamlandırmak gerekir." (K30)

Tablo 3. Doktora öğrencilerinin doktora eğitimine ilişkin metaforlarının kategorilendirilmesi

\begin{tabular}{llll}
\hline Kategori & Metaforlar & $\mathrm{f}$ & $\%$ \\
\hline Olumlu & güneş (2), vitamin, yeni bir dünyayı keşif, inşa edilmesi gereken & 29 & 51.7 \\
& bina, kök, reçete, serüven, omuzdaki rütbe, en sevdiğim tatlı, & & \\
& bilgisayar, son rötuş, kendini gerçekleştirmek, örümcek ağı, & & \\
& anahtar, okyanus, kütüphane, akarsu, geleceğe açılan bir yol, & \\
& zorlu ama vazgeçilmez bir yol, piknik, merdiven, merdiven & \\
& çıkmak, bol bonuslu oyun, tropik orman, tünel, basamak, hayat, & \\
& sindirim & & \\
\hline Olumsuz & estetik operasyon, boşa kürek çekmek, dipsiz kuyu, amelelik, ilaç, & 25 & 44.6 \\
& ek iş yapmak, Uludağ, damat adayına ikram edilen tuzlu kahve, & \\
& hayat, dikenli bir yol, Mario oyunu, buzdağı, nereye çıkacağı & \\
& belirsiz yol, arena, çileli bir yolculuk, ayağın altına yapışan sakız, & \\
& zorlu bir maraton, uzunca bir seyahate çıkan gezgin, kaktüs, & \\
& tünel, pişme süreci, yeni maceralara yelken açmak, maden & \\
& aramak, merdiven, istediğim yere varan yokuş & 2 & 3.7 \\
\hline
\end{tabular}

Tablo 3'te doktora eğitimine yönelik metaforların gerekçelerine göre sınıflandııılması yer almaktadır. Buna göre metaforlar olumlu, olumsuz ve yansız olmak üzere üç ana kategoride toplanmıştır. Olumlu kategoride 29 metafor (\%51.7); olumsuz kategoride 25 metafor (\%44.6) ve yansız kategoride ise 2 metafor (\%3.7) yer almaktadır. Bu metaforların gerekçeleri göz önüne alındığında ise; olumlu algıları yansıtan metaforların genellikle doktora eğitiminin bireye yeni ufuklar açtığı, kendini gerçekleştirme imkânı sunduğu ve bireyin bilgi dağarcığını zenginleştirdiği gibi gerekçelere dayandırıldığ görülmektedir. Öte yandan olumsuz algıları yansıtan metaforların gerekçeleri dikkate alındığında ise doktora eğitim sürecinin zorluğu ve sonucunun öngörülemezliği / belirsizliği barındırması gibi gerekçeler ortaya konduğu görülmektedir. Aşağıda her üç kategoriye ait katılımcı ifadelerinden örnekler yer almaktadır.

Olumlu Algilara Örnek Ifadeler:

"Doktora eğitimi hayat gibidir. Çünkü vazgeçilmezdir; doktora bitmezse hiçbir şeymişim gibi hissedeceğim." (K25)

"Doktora eğitimi tünel gibidir. Çünkü ne kadar uzakta olduğu bilinmeyen bir ışık görünür, yol meşakkatlidir ama tünelden çıktığında olgun ve mutlusundur." (K7)

"Doktora eğitimi merdiven gibidir. Çünkü mesleki anlamda kendimi gerçekleştirmem için bir araçtır." (K53)

"Doktora eğitimi merdiven çıkmak gibidir. Çünkü hep yükseklere çıkarsın." (K55)

"Doktora eğitimi yeni bir dünyayı keșfetmek gibidir. Çünkü yepyeni şeyler öğrenirim." (K10) 
"Doktora eğitimi en sevdiğim tatlı gibidir. Çünkü bir mesleğin vardır. Zorunluluk değildir doktora eğitimi almak. Ancak tatı nasıl yemekten sonra ayrı bir zevk verirse doktora eğitimi de ayrı bir öğrenme zevki yaşatır insana." (K29)

"Doktora eğitimi anahtar gibidir. Çünkü bir basamak atlamak demektir. Lisans veya Yüksek lisans mezunu işgörenlere göre bir adım önde olmaktır. Dolayısılla diğerlerine göre açılması zor olan bazı kapıları nispeten daha kolay açılmasını sağlar. Ayrıca kariyer planlamasında büyük bir adım olduğu için toplumsal statü açısından yükselmeye yardım sağlar." (K44)

"Doktora eğitimi örümcek ağı gibidir. Çünkü bilgiye ulaştıkça ve bilgiyi işledikçe eğitim öğrenim ağının genişlediğini fark ettim" (K42)

Olumsuz Algılara Örnek Ifadeler:

"Doktora eğitimi hayat gibidir. Çünkü hayatın içinde çoğu zaman engebeli yollar ile karşılaşırsınız." (K17)

"Doktora eğitimi tünel gibidir. Çünkü içine girdiğinizde yolun sonunu göremezsiniz kimi zaman aydınlıktır kimi zaman karanlık hızlanınca yolun sonuna daha çabuk ulaşırsınız yavaşlarsanız karanlıkta gitmeye devam edersiniz." (K51)

"Doktora eğitimi merdiven gibidir. Çünkü sürekli geçilmesi gereken bir basamak vardır." (K39)

"Doktora eğitimi yeni maceralara yelken açmak gibidir. Çünkü bütün sorumluluklarının yanına başka bir sorumluluk ekleyip kendini zorluyorsun." (K26)

"Doktora eğitimi boșa kürek çekmek gibidir. Çünkü akademide alımlar liyakate göre değil ikili ilişkilere göredir." (K5)

"Doktora eğitimi dipsiz kuyu gibidir. Çünkü danışmanımın yardımı olmadan bir şeyler yapmaya çalışıyorum." (K6)

"Doktora eğitimi amelelik gibidir. Çünkü zihinsel geviş getirmekten başka bir şey değildir."(K8)

"Doktora eğitimi ayağın altına yapışan sakız gibidir. Çünkü her adımda rahatsız ediyor ama eğilip temizlemeye üşeniyorum." (K32)

"Doktora eğitimi kaktüs gibidir. Çünkü neresinden tutarsan tut batar." (K38)

Yansız Algilara Örnek Ifadeler:

"Doktora eğitimi geleceğim gibidir. Çünkü geleceğim doktoramla büyük oranda ilişkili." (K4)

"Doktora eğitimi_gökyüzü gibidir. Çünkü orada ya kendimizi bulur mutlu ve özgür oluruz ya da kendimi kaybeder mutsuz ve birilerine bağımlı oluruz." (K32)

Tablo 4. Öğretim üyelerine yönelik üretilen metaforlar

\begin{tabular}{lll}
\hline Metaforlar & & \\
\hline rehber (6) & kız babası & farklı boyutlarda dişli çarklar \\
arkadaş (4) & aşçı & ışık \\
pusula (3) & çocuk & dolu gibi görünen boş havuz \\
fener (3) & kuyu kovası & Google \\
güneş (2) & farklı meyveler & tecrübe \\
kutup yıldızı (2) & aktardaki bitkiler & dünya mutfağı \\
usta (2) & satranç taşları & davul \\
konuşup bir şey yapmayan adam & kaprisli sanatçılar & diktatör \\
kitap özeti & arenadaki aslanlar & bilgisayar \\
Tüccar & korkulası kişiler & yol göstericiler \\
derlenmiş kitap & buzdağı & Olympos Dağındaki Tanrılar \\
sodalı ayran & örnek aldığım idoller & aile \\
hayranlık duyduğum kahramanlar & gökkuşağı & OHAL Valisi \\
Kitaplık & hakim & \\
gizemli bir kutu & kapı & \\
\hline
\end{tabular}

Tablo 4'te katııımcıların öğretim üyelerine yönelik ortaya koydukları metaforlar sunulmaktadır. Buna göre 63 katıımcı 43 farklı toplam 58 metafor üretmiştir. Beş katıımcının ürettikleri ifadeler ise ya metafor niteliği taşımadığından ya da metafor ve gerekçe arasından tutarsızlık olduğundan 
kapsam dışında tutulmuştur. Tablo 4 incelendiğinde; rehber $(f=6)$, arkadaş $(f=4)$, pusula $(f=3)$, fener $(f=3)$, güneş $(f=2)$, kutup yıldızı $(f=2)$ ve usta $(f=2)$ en fazla tekrar eden metaforlar olarak göze çarpmaktadır. 63 katıımcının 43 farklı metafor ürettiği dikkate alındığında, katılımcıların öğretim üyelerine yönelik algılarının oldukça çeşitlilik arz ettiği söylenebilir. Aşağıda katıımcıların ifadelerinden örnekler yer almaktadır.

Örnek ifadeler:

"Programdaki öğretim üyeleri çocuk gibidir. Mutlu olduğunda her şey çok güzeldir ancak mutsuz olduğunda burnunuzdan getirir." (K22)

"Programdaki öğretim üyeleri Olympos Dağı'ndaki Tanrılar gibidir. Çünkü buna beni inandırdılar." (K35)

"Programdaki öğretim üyeleri ışık gibidir. Sadece derslerde değil hayatı da anlamlandırmama yardıma olurlar." (K37)

"Programdaki öğretim üyeleri rehber gibidir. Çünkü bu yolda nelerle karşılaşabileceğimi, problem durumunda nasıl tepki verileceğini yaşam boyu eğitimin nasıl uygulamaya geçirileceğini gösterirler" (K45) "Programdaki öğretim üyeleri pusula gibidir. Çünkü doktora eğitimi çoğunlukla öğrenci çabasına bağlıdır. Bu zorlu süreci tamamlamak amacınızı, yöntemlerinizi ve sonunda varmak istediğiniz noktayı siz belirlersiniz. Öğretim üyeleri ise deneyimleri ve bilgileriyle daima bu yolda size doğru yönü göstermeye hazırdırlar." (K46)

Tablo 5. Doktora öğrencilerinin öğretim üyelerine ilişkin metaforlarının kategorilendirilmesi

\begin{tabular}{llcc}
\hline Kategori & Metaforlar & $\mathrm{f}$ & $\%$ \\
\hline Olumlu & rehber (6), arkadaş (3), pusula (3), fener (3), kutup & 38 & 67 \\
& yıldızı (2), dünya mutfağı, farklı boyutlarda dişli & & \\
& çarklar, kitap özeti, derlenmiş kitap, hayranlık & & \\
& duyduğum kahramanlar, aile, aşçı, kuyu kovası, \\
& farklı meyveler, aktardaki bitkiler, örnek aldığım \\
& idoller, yol göstericiler, ışı, Google, güneş, kitaplık, & \\
& gökkuşağı, kapı, tecrübe, satranç taşları, usta & \\
\hline Olumsuz & $\begin{array}{l}\text { tüccar, konuşup bir şey yapmayan adam, usta, } \\
\text { arenadaki aslanlar, korkulası kişiler, Olympos }\end{array}$ & \\
& $\begin{array}{l}\text { Dağındaki Tanrılar, dolu gibi görünen boş havuz, } \\
\text { davul, diktatör, OHAL Valisi, hakim, kız babası }\end{array}$ & \\
\hline İki Yönlü & sodalı ayran, çocuk, kaprisli sanatçılar, buzdağı, & \\
(Olumlu ve Olumsuz) & güneş, bilgisayar, gizemli bir kutu & 12 \\
\hline Yansız & arkadaş & 1 & 1.7 \\
\hline
\end{tabular}

Tablo 5'te katılımcıların öğretim üyelerine yönelik ortaya koydukları metaforların gerekçelerine göre sınıflandırılması sunulmaktadır. Buna göre metaforlar; olumlu, olumsuz, bir yönüyle olumlu bir yönü ile olumsuz ve yansız olmak üzere dört kategoride toplanmıştır. Öğretim üyelerine yönelik metaforlar gerekçelerin niteliklerine göre kategorilere ayrıldığında; 38 metaforun olumlu algıları (\%67), 12 metaforun olumsuz algıları (\%20.6), 7 metaforun hem olumlu hem olumsuz algıları (\%12) ve 1 metaforun da yansız algıları (\%1.7) yansıttığı görülmektedir. Bu metaforların gerekçeleri göz önünde bulundurulduğunda ise; olumlu algıları yansıtan metaforların genellikle öğretim üyelerinin yol göstericilik / rehberlik, bilgi kaynağı olma ve sahip olduğu uzmanlık ile entelektüel anlamda zenginlik katma gibi gerekçelere dayandırıldığı görülmektedir. Olumsuz algıları yansıtan metaforların gerekçeleri ise genelde öğretim üyelerinin zaman zaman öğrencilere zorluk çıkarmaları ve davranışlarında tutarsızlık gözlenmesi olarak göze çarpmaktadır. iki yönlü metaforların da yine öğretim üyelerinin bazen öğrencilere akademik anlamda katkı sunduğu ancak bazen ise zorluk çıkardığı şeklinde gerekçelendirilmiştir. Aşağıda katılımcıların ifadelerinden örnekler yer almaktadır.

Olumlu Algilara Örnek ifadeler:

"Programdaki öğretim üyeleri farklı boyutlarda diş̧i çarklar gibidir. Çünkü dişli çarkların sadece biri döndüğünde diğerinin dönmesine sebep olurken çark olma hedefi olan tek diş olan beni çarklardan 
akan su/bilgi büyütüyor, her bir çark kendine ait suyu/bilgiyi akıtırken melezleşen materyal beni ben yapacak olan özü oluşturuyor." (K3)

"Programdaki öğretim üyeleri dünya mutfağı gibidir. Çünkü dünya mutfaklarında farklı lezzetler olduğu gibi öğretim üyelerinin kendine has özellikleri, bilgi ve tecrübelerinden ilham alarak farklı deneyimler yaşar, farklı şeyler öğreniriz." (K2)

"Programdaki öğretim üyeleri yolumu aydınlatan fener gibidir. Çünkü önümü görürüm ve yalnız olmadığımı hissederim." (K13)

"Programdaki öğretim üyeleri farklı meyveler gibidir. Çünkü hepsinden farklı bir tat alırsın ve en çok beğendiğin ile çalışırsın." (K24)

"Programdaki öğretim üyeleri Google gibidir. Çünkü merak ettiğim bilgiyi bana sunarlar." (K39)

"Programdaki ögretim üyeleri kutup yıldızı gibidir. Çünkü umuda yürürken yolumu kaybetmememi sağlar. Bana rehberlik eder." (K40)

Olumsuz Algılara Örnek Ifadeler:

"Programdaki öğretim üyeleri usta gibidir. Çünkü bana ameleliği öğrettiler." (K9)

"Programdaki öğretim üyeleri dolu gibi görünen boș havuz gibidir. Çünkü belli bir akademik unvanı aldıktan sonra, boş vermişlik, vurdumduymazlık ve derinlik maalesef kendilerinde mevcuttur." (K38)

"Programdaki öğretim üyeleri davul gibidir. Çünkü sesleri çıkar ama içleri boştur." (K42)

"Programdaki öğretim üyeleri diktatör gibidir. Çünkü tek onların bildikleri doğru gibi davranırlar. Farkı perspektiflere sahip olmak onların gözünde bir eksidir." (K43)

"Programdaki öğretim üyeleri OHAL Valisi gibidir. Çünkü birçoğu insan ilişkilerini çok önemsemeyen, varsa yoksa kural diyen, fırsatını buldukça, karşısındaki doktora öğrencisinin öğretmen müdür, müdür yardımcısı veya yaşını başını almış iş güç sahibi biri olduğunu unutarak çocuk gibi azarlayan kişilerdir. Hâlbuki oraya eğitim almaya gelen kişiler, tamamen gönüllü olarak iç motivasyonu tam olan, iş ve sosyal yaşamından zaman kısarak gerekli ödev ve görevleri yerine getirmeye çalışırlar. Sırf bu gerçeklerden yola çıkarak öğretim üyelerinin daha çok yardımcı olması, motivasyon düşüren, engel olan, korkulan değil; destekleyen yol gösteren ve sevilen karakterler olması gerekmektedir." (K44)

"Programdaki öğretim üyeleri hakim gibidir. Çünkü hakkınızda bir yargıları oluşursa onu kırmak çok zor oluyor." (K54)

iki Yönlü Algulara Örnek ifadeler:

"Programdaki öğretim üyeleri buzdağı gibidir. Çünkü istediği zaman istediği yüzünü gösteriyor. Bazen suyun üstünü bazen suyun altını." (K21)

"Programdaki öğretim üyeleri çocuk gibidir. Çünkü mutlu olduğunda her şey çok güzeldir ancak mutsuz olduğunda burnunuzdan getirir." (K22)

"Programdaki öğretim üyeleri kaprisli sanatçılar gibidir. Çünkü işlerini iyi yaparlar ama kapris yapmayı da ihmal etmezler." (K27)

"Programdaki öğretim üyeleri bilgisayar gibidir. Çünkü bazen yanında taşıması ağırlık yapar. Yorulursun. Kimi zaman da öyle bilgiler edinirsin ki kıymeti ölçülemez." (K33)

"Programdaki öğretim üyeleri gizemli bir kutu gibidir. Çünkü gizemli kutuyu açtığınızda yeni görüş açıları, bilgiler saçabilir ama aynı zamanda korkmanıza şaşırmanıza da neden olabilir kutunun içinden çıkanlar" (K58)

Yansız Algılara Örnek ifadeler:

"Programdaki öğretim üyeleri arkadaş gibidir. Çünkü akranız." (K14)

\section{SONUÇ VE TARTIŞMA}

Metaforlar gündelik konuşmaları süslemenin ötesinde bir işleve sahip olup (Saban, 2008); bireylerin deneyimlerini anlamlandırmak için önemli bir edebi araç olarak kullanılabilirler (Miles, Huberman ve Saldana, 2014). Bu çalışmada da doktora öğrencilerinin doktora eğitim sürecine ve öğretim üyelerine yönelik deneyimlerini ortaya çıkarmak amacıyla metaforlardan yararlanılmıştır. Bu bağlamda 63 doktora öğrencisine ulaşılmıs; yarı yapılandırılmış iki sorudan oluşan bir form aracılığıyla veri toplanmıştır. Doktora eğitimine yönelik ortaya konan 63 ifadeden 56 'sı analize dahil 
edilmiş yedi ifade ise farklı gerekçelerle analiz dışı tutulmuştur. Katılımcıların doktora eğitimine yönelik 52 farklı metafor ürettikleri görülmüştür. Bu metaforlardan sadece güneş, tünel, hayat ve merdiven metaforları tekrar etmiştir. Bu sonuç katılımcıların algılarının çeşitlilik arz ettiğine işaret etmektedir. Söz konusu ifadeler metafora ilişkin gerekçeden yola çıkılarak olumlu, olumsuz ve yansız olmak üzere üç kategoride toplanmıştır. 56 metaforun yaklaşık \%51'i olumlu algıları; \%45'i olumsuz algıları ve \%4'ü ise yansız algıları yansıtmaktadır. Bu açıdan katılımcıların neredeyse yarısının almış oldukları eğitime yönelik olumsuz algılara sahip oldukları söylenebilir. Özmen ve Aydın Güç (2013) doktora eğitimine ilişkin zorlukları ve bu zorluklar ile baş etme stratejilerini ortaya koydukları çalışmada süreçte yaşanan sıkıntılara değinmişlerdir. Söz konusu çalışmada katılımcılar zaman, iş yükü, özel hayat, ulaşım, deneyim, danışman, alan hakimiyeti ve dersler, danışman, veri tabanı kullanımı, Ingilizce ve maddi sebeplerden dolayı birtakım zorluklar yaşadıklarını ifade etmişlerdir. Bu bağlamda, ifade edilen bu gibi sebeplerin mevcut araştırma katılımcılarının da doktora eğitimine yönelik algılarını olumsuz yönde etkilemekte olduğu düşünülebilir. Öte yandan, olumlu algılar genelde doktora eğitiminin öğrencilere yeni ufuklar açtı̆̆ı, kendini geliştirme imkanı sunduğu ve bilgi dağarcıklarını zenginleştirdiği gibi gerekçelere dayandırılmaktadır. Güleç ve GüleçAslan (2013) ve Şaşmaz Ören, Yılmaz ve Güçlü (2012) lisansüstünden beklentilere yönelik yürüttükleri çalışmalarda katılımcıların kariyer, mesleki gelişim ve süreci tamamlayabilme gibi beklentiler içinde oldukları görülmektedir. Mevcut araştırma ile karşılaştırıldığında sürecin içinde yer alan katılımcıların da benzer algılara sahip oldukları görülmektedir. Bozpolat (2016) benzer şekilde lisansüstü eğitime yönelik metaforları gelişim ve keşif gibi temalar altında toplamıştır. Bu açıdan da mevcut araştırmanın alan yazın ile paralellik gösterdiği söylenebilir. Olumsuz algıları yansıtan metaforlar ise eğitim sürecinin zorluğuna ve sonucunun öngörülemezliğine dayandırılmaktadır. Bozpolat (2016) lisansüstü eğitime yönelik metaforları çaba ve zorluk gibi kategoriler altında toplamıştır. Bu bağlamda da iki araştırma bulguları uyuşmaktadır. Araştırmada ele alınan ikinci olgu ise öğretim üyeleridir. 63 katılımcı öğretim üyelerine yönelik 43'ü farklı olmak üzere geçerli 58 metafor üretmiştir. Bu ifadelerden rehber, arkadaş, pusula, fener, güneş, kutup yıldızı ve usta metaforları tekrar etmiştir. Öğretim üyelerine yönelik metaforlar metafora ilişkin gerekçelere dayanarak olumlu, olumsuz, iki yönlü (hem olumlu hem olumsuz) ve yansız olmak üzere dört kategoride toplanmıştır. 58 metaforun yaklaşık olarak \%67'si olumlu algıları; \%20'si olumsuz algıları; \%12'si iki yönlü ve \%2'si de yansız algıları yansıtmaktadır. Eğitim süreci ile karşılaştırıldığında öğretim üyelerine yönelik algıların daha olumlu olduğu anlaşılmaktadır. Bu bulgu öğretim üyelerinin öğrenciler ile ilişkilerini iyi yönettikleri yorumuna imkan verir niteliktedir. Olumlu algıları yansıtan metaforlar genel olarak yol göstericilik, rehber olma, bilgi kaynağı olma ve katılımcılara sunulan entelektüel destek gibi gerekçelere dayandırılmaktadır. Alan yazında lisansüstü eğitim sorunlarını irdeleyen araştırmalar genelde öğretim üyelerinden özelde danışmandan kaynaklanan sorunlara çokça değinmektedir (Gürgan Öztürk ve Dinç, 2016; Çoruk Çağatay ve Öztürk, 2016; Aydoğmuş, 2016; Alabaş, Kamer ve Polat, 2012). Bu açıdan mevcut araştırmanın alan yazından farkıı bir bulgu ortaya koyduğu söylenebilir. Öte yandan, öğretim üyelerine yönelik olumsuz algıları yansıtan metaforlar ise genellikle katılımcılara zorluk çıkarmaları ve tutarsız davranışlar sergilemeleri gibi gerekçelere dayandırılmaktadır.

\section{5. ÖNERILER}

Doktora öğrencilerinin doktora eğitimi ve öğretim üyelerine yönelik algılarını metaforlar aracılığı ile belirlemeyi amaçlayan bu çalışma, metafor formunda mevcut iki ifade ile sınırlıdır. Ayrıca nitel desende tasarlanmış bu çalışma, çalışma grubundan elde edilen veriler ile sınırlıdır. Bu sınırlııklar içerisinde araştırma bulgularına dayalı olarak ve gelecek çalışmalara yönelik şu öneriler getirilmiştir:

- Doktora öğrencilerinin mezuniyet sonrası süreçteki belirsizliğe yönelik endişelerini ortadan kaldırmak amacıyla, kamu sektöründe işe alımlarda doktora mezunu adaylara daha fazla öncelik tanınmalıdır. 
- Öğretim üyesi yetiştirme programı (ÖYP) veya 33/a gibi öğrencilerin hem doktora eğitimi görmeleri hem de istihdamına yönelik uygulamalar devam ettirilerek yaygınlaştırılmalıdır. Böylece hem öğrencilerin motivasyonu sağlanmış hem de algılanan belirsizlik ortadan kaldırılmış olacaktır.

- Bir yandan çalışıp diğer yandan doktora eğitimine devam eden doktora öğrencilerine yönelik birtakım kolaylıklar sağlanmalıdır. Örneğin; Milli Eğitim Bakanlığı'nda görevli olup doktora eğitimi alan öğretmenlerin haftalık ders yükleri azaltılabilir.

- Lisansüstü öğretim programlarında süreç içerisindeki olumsuzlukları belirlemek amacıyla öğrencilerin aktif bir şekilde dahil olduğu daha sağlıklı ve işlevsel öz değerlendirme etkinlikleri yürütülmelidir.

- Doktora öğrencileri ile ilgili daha geniş nicel desende araştırmalar yürütülebilir.

- Doktora programını tamamlamış ve öğrenciliği devam eden bireyler üzerinde karşılaştırmalı araştırmalar yürütülebilir.

- Doktora eğitimine yönelik boylamsal çalışmalar yürütülerek; öğrencilik öncesi mülakat, ders dönemi, yeterlilik dönemi ve tez dönemine yönelik algılar ayrıntılı bir şekilde ortaya konabilir.

- Öğretim üyelerinin bakış açısıyla doktora öğrencilerini ele alan nitel veya nicel çalışmalar yürütülebilir.

Yine öğretim üyelerinin bakış açısıyla doktora eğitimi ve meslektaşlara yönelik algıları ortaya çıkarmayı amaçlayan çalışmalar yürütülebilir.

\section{Kaynakça}

Alabaş, R., Kamer, T. S. ve Polat, Ü. (2012). Öğretmenlerin Kariyer Gelişimlerinde Lisansüstü Eğitim: Tercih Sebepleri ve Süreçte Karşılaştıkları Sorunlar. e-international journal of educational research, 3(4), 89-107.

Aslan, C. (2010). Türkçe Eğitimi Programlarında Lisansüstü Öğrenim Gören Öğrencilerin Akademik Özyeterliklerine Illişkin Görüşleri. Mehmet Akif Ersoy Üniversitesi Eğitim Fakültesi Dergisi, 10(19), 87-115.

Aslan, C. ve Karagül, S. (2016). Türkçe Eğitimi Programında Lisansüstü Öğrenim Gören Öğrencilerin Bilimsel Araştırma Yapmaya Yönelik Kaygı Düzeyleri. Mehmet Akif Ersoy Üniversitesi Eğitim Fakültesi Dergisi, 38, 201-217.

Aydoğmuş, Y. (2015). Akademisyenlerin Türkiye'deki Lisansüstü Coğrafya Eğitimine Yönelik Görüşleri, Coğrafya Eğitimi Dergisi, 1(2), 31-42.

Bahar-Güner, Ö., Tunca, N., Alkın-Şahin, S. ve Oğuz, A. (2015). Öğretmen Adaylarının Öğretmen Eğitimcisine Iliş̧kin Metaforik Algıları. Pegem Eğitim ve Öğretim Dergisi, 5(4), 419-444, http://dx.doi.org/10.14527/pegegog.2015.023.

Balcı, A. (2013). Doktora Programı: Türk Üniversiteleri Doktora Programları İçin Bazı Öneriler. Eğitim Bilimleri Araştırmaları Dergisi, 3(2), 1-20.

Bernstein, B. L., Evans, B., Fyffe, J., Halai, N., Hall, F. L., Jensen, H. S., Marsh, H. ve Ortega, S. (2014). The Continuing Evolution of the Research Doctorate. Maresi Nerad \& Barbara Evans (Ed). Globalization and Its Impacts on the Quality of PhD Education içinde (s. 5-30). Rotterdam: Sense Publishers.

Bøgelund, P. (2015). How Supervisors Perceive PhD Supervision - And How They Practice It. International Journal of Doctoral Studies, 10, 39-55. Retrieved from http://ijds.org/Volume10/IJDSv10p039-055Bogelund0714.pdf.

Bozpolat, E. (2016). Öğretmen Adaylarının Lisansüstü Eğitime Illişkin Metaforik Algıları. İlköğretim Online, 15(4), 1114-1130. doi: http://dx.doi.org/10.17051/io.2016.90433. 
Çelikkaya, T., Yakar, H. ve Şarlayan, R. (2016). Öğrencilerin Sosyal Bilgiler Dersindeki Saygı ve Bilimsellik Değerlerine Iliş̧kin Algıları: Metafor Analizi. International Online Journal of Educational Sciences, 8(3), 143-165

Çoruk, A., Çağatay, Ş. M. ve Öztürk, H. (2016). Lisansüstü Eğitimde Kayıt ve Devam Sorunları. Uşak Üniversitesi Sosyal Bilimler Dergisi, 9(1), 165-178. DOI: 10.12780/uusbd.73894.

Döş, i. (2011). Okul Paydaşlarının Metaforlar Yardımılla Okul Örgütlerini Algılama Biçimlerinin Değerlendirilmesi. Doktora Tezi, Fırat Üniversitesi Sosyal Bilimler Enstitüsü, Elazığ.

Eggins, H. (2008). Trends and issues in postgraduate education: a global review. Trends and Issues in Postgraduate Education: Challenges for Research International Experts Workshop. 5-7 March. Dublin City University, Dublin, Ireland.

Ekici, G. (2016). Biyoloji Öğretmeni Adaylarının Mikroskop Kavramına iliş̧kin Algılarının Belirlenmesi: Bir Metafor Analizi Çalışması. Ahi Evran Üniversitesi Kırşehir Eğitim Fakültesi Dergisi (KEFAD), 17(1), 615-636.

Golde, C. M. ve Dore, T.M. (2001). At Cross Purposes: What the experiences of today's doctoral students reveal about doctoral education. The Pew Charitable Trusts. http://www.phdsurvey.org/report\%20final.pdf adresinden 15.06.2017 tarihinde erişilmiştir.

Güleç, İ. ve Güleç-Aslan, Y. (2013). Af Kanunu ile Lisansüstü Eğitime Yeniden Başlayan Öğrencilerin Deneyimlerinin İncelenmesi. Eğitim ve Öğretim Araştırmaları Dergisi, 2(4), 270-276.

Güner, G. (2006). Yüksek Lisans ve Doktora Eğitimi. IV. Ulusal Tıp Eğitimi Kongresi, 2-5 Mayıs, Adana.

Gürgan Öztürk, F. ve Dinç, H. (2016). Lisansüstü Eğitim Alan Müzik Öğretmenlerinin Karşılaştıkları Sorunlar. İdil, 5(21), 505-520. DOI: 10.7816/idil-05-21-15.

Hark Söylemez, N., Dokumacı Sütçü, N. ve Sütçü, K. (2014). Lisansüstü Eğitim Gören Öğrencilerin Özerk Öğrenme Becerilerine Illişkin Algıları. Bilgisayar ve Eğitim Araştırmaları Dergisi, 2(4), 91-110.

İpek Akbulut, H., Şahin, Ç. ve Çepni, S. (2013). Doktora Tez Sürecinde Karşılaşılan Problemlerin Belirlenmesi: Eğitim Fakültesi Örneği. Dicle Üniversitesi Ziya Gökalp Eğitim Fakültesi Dergisi, 20, 50-69.

Joyner, S. A., Fuller, M. B., Holzweiss, P. C., Henderson, S. ve Young, R. (2014). The Importance of Student-Instructor Connections in Graduate Level Online Courses. MERLOT Journal of Online Learning and Teaching, 10(3), 436-445.

Kahyaoğlu, M. ve Kırıktaş, H. (2016). Ortaöğretim ve Üniversite Öğrencilerinin "Doğa" Kavramına İlişkin Algılarının Metaforlar Analizi Yoluyla İncelenmesi. Marmara Coğrafya Dergisi, 33, 58-76.

Karakütük, K. (1989). Türkiye'de Lisansüstü Öğretim, Sorunları ve Çözüm Önerileri. Ankara Üniversitesi Ĕgitim Bilimleri Fakültesi Dergisi, 22(1), 505-528.

Karaman, S. ve Bakırcı, F. (2010). Türkiye'de Lisansüstü Egitim: Sorunlar ve Çözüm Önerileri. Sosyal Bilimler Araştırmaları Dergisi, 2, 94-114.

Kasapoğlu, H. (2016). Öğretmen Adaylarının Türk Eğitim Sistemine illişkin Algılarının Metaforlar Yoluyla Analizi. Kuram ve Uygulamada Eğitim Yönetimi, 22(1), 59-80. doi: 10.14527/kuey.2016.003.

Kendall, J. ve Kendall, K. (1993). Metaphors and Methodologies: Living Beyond the Systems Machine. MIS Quarterly, 17(2), 149-171.

Meral, E., Küçük, B. ve Gedik, F. (2016). Sosyal Bilgiler Öğretmen Adaylarının Çevre Kavramına iliş̧kin Metaforik Algıları. Kastamonu Eğitim Dergisi, 24(1), 65-78.

Mertens, D. M. (2010). Research and evaluation in education and psychology: integrating diversity with quantitative, qualitative, and mixed methods. California: Sage.

Miles, M. B. ve Huberman, A. M. (1994). Qualitative data analysis: An expanded sourcebook (2nd ed.). Thousand Oaks, CA: Sage.

Miles, M. B., Huberman, A. M. ve Saldana, J. (2014). Qualitative data analysis a methods sourcebook. (3rd ed.). Thousand Oaks, CA: Sage. 
Ogurlu, Ü., Öpengin, E. ve Hızlı, E. (2015). Üstün Yetenekli Öğrencilerin Okul ve Öğretmene İlişkin Metaforik Algıları. Dumlupınar Üniversitesi Sosyal Bilimler Dergisi, 46(Ekim), 67-83.

Özmen, Z. M. ve Aydın Güç, F. (2013). Doktora Eğitimi ile Illgili Yaşanan Zorluklar ve Baş Etme Stratejileri: Durum Çalışması. Yükseköğretim ve Bilim Dergisi, 3(3), 214-219. DOI: 10.5961/jhes.2013.079.

Renz Lisa, M. (2009). Metaphor: Imagery Devices Used by Morgan to Describe Organizations as Culture and Psychic Prisons. Emerging Leadership Journey, 2(1), 54-65.

Resmi Gazete (2016). Lisansüstü Eğitim ve Öğretim Yönetmeliği. (Sayı: 29690).

Rugg, G. ve Petre, M. (2007). A gentle guide to research methods. Berkshire: Open University.

Saban, A. (2008). Okula Illişkin Metaforlar. Kuram ve Uygulamada Eğitim Yönetimi, 55, 459-496.

Şahin, M. H. ve Kaya, H. (2016). Sosyal Bilgiler Öğretmen Adaylarının Bazı Coğrafya Kavramlarına İlişkin Algılarının Metaforlar Yoluyla Analizi. Eğitim ve Öğretim Araştırmaları Dergisi, 5 (Özel Sayı), s. $111-120$.

Şahin, Ç., Demir, M. K. ve Arcagök, S. (2015). Öğretmen Adaylarının Lisansüstü Eğitime Yönelik Görüşleri. Eğitimde Kuram ve Uygulama, 11(1), 304-320.

Şaşmaz Ören, F., Yılmaz, T. ve Güçlü, M. (2012). Öğretmen Adaylarının Lisansüstü Eğitime Yönelik Görüşlerinin Analizi. Eğitim ve Öğretim Araştırmaları Dergisi, 1(2), 189-201.

Şen, Z. (2013). Türkiye'de Yüksek Lisans ve Doktora Eğitimi Kalitesinin İyileştirilmesi için Öneriler. Yükseköğretim ve Bilim Dergisi, 3(1), 10-15. DOI: 10.5961/jhes.2013.054.

Tiryaki, E. N. ve Demir, A. (2016). Türkçe Öğretmeni Adaylarının Yazma Becerisine Yönelik Metaforik Algıları. Mustafa Kemal Üniversitesi Sosyal Bilimler Enstitüsü Dergisi, 13(33), 18-27.

Tulunay Ateş, Ö. (2016). Öğrencilerin Öğretmen ve Okul Metaforları. International Journal of Contemporary Educational Studies (Int/CES), 2(1), 78-93.

Tünkler, V., Tarman, B. ve Güven, C. (2016). Vatandaşlık ve Demokrasi Öğretim Programında Yer Alan Somut Kavramların ve Değerlerin Öğrencilere Kazandırılmasına Illişkin Metaforik Bir Yaklaşım. Eğitim ve Bilim, 41(185), 123-145. DOI: 10.15390/EB.2016.6031.

Uslu, N., Kocakülah, A. ve Gür, H. (2016). Ortaokul Öğrencilerinin Bilim, Bilim İnsanı ve Öğretmen Kavramlarına Iliş̧kin Metafor Algılarının İncelenmesi. Eğitim ve Öğretim Araştırmaları Dergisi, 5(1), 354-364.

Yalçın, M., Aydoğdu Özoğlu, E. ve Dönmez, A. (2016). Öğretim Elemanlarının Araştırma Görevlisi Kavramına Illişkin Metaforik Algıları. Eğitim ve Bilim, 41(185), 19-32. DOI: 10.15390/EB.2016.4435.

Yalçın Wells, Ş. (2015). Görsel Sanatlar Öğretmeni Adaylarının Öğretmen ve Sanatçı Algısına ilişkin

Metafor Analizi. Hacettepe Üniversitesi Eğitim Fakültesi Dergisi, 30(3), 160-175.

Yılmaz, S. (2011). İlköğretim Okul Yönetici ve Öğretmenlerinin Çalıştıkları Kuruma Yönelik Örgütsel Metafor Algıları (Kastamonu illi Örneği). Yüksek Lisans Tezi, Eğitim Fakültesi, Kastamonu.

Yıldırım, A. ve Şimşek, H. (2016). Sosyal bilimlerde nitel araştırma yöntemleri (10. Baskı). Ankara: Seçkin.

YÖK. (2015). http://www.yok.gov.tr/web/ogrenci/yuksek-lisans-ve-doktora-kriterleri-guncellendi adresinden 24.02.2017 tarihinde erişilmiştir. 


\section{Extended Summary}

Postgraduate education, especially Phd education, has become a prominent issue recently in international context. Under the influence of Bologna Process and globalization, the need for a system which will train qualified people needed by nations has become clearer. Aforementioned manpower plays a crucial role in moving their societies among knowledge and financially powerful ones. In line with these objectives universities open postgraduate departments. Thus, they educate people who are creative, analyst, respectful to ethical values, find rationale solutions to the problems, have scientific viewpoint, produce scientific studies, participate in group and multidisciplinary studies and respond to the needs of their societies. On the other hand, postgraduate education can be defined as a process contributing to individuals' personal and occupational development.

Phd programs are expected to contribute to existing knowledge, bring in expertise for the graduates in their field and include transferrable competencies and skills. So, the programs must have some standards. The Council of Higher Education updated the criterion to open postgraduate programs in 2015 . This initiative can be regarded as a substantial step in increasing the quality of the programs. In addition to these efforts in increasing the quality of the programs, there has been a considerable rise in the number of students registered to Phd programs. The number of the Phd students has stepped up to 91267 from 67157 during the last four years. This increase has gained the attention of the researchers. However, it can be seen that the studies on postgraduate students mostly deal with their problems. The aim of this study is to determine the Phd students' perceptions about their education and instructors by means of metaphors which is a commonly used tool in scientific studies recently.

This is a qualitative study designed in phenomenological approach which aims to determine individuals' perceptions of or the meaning they attribute to a phenomena or an experience. The aim of this approach is to understand the phenomena or the experience from the viewpoint of the participants. What is different about this approach is that the subjective experiences of the participants are at the core of the study. The phenomena dealt with in this study are Phd education and instructors.

To determine the perceptions of the participants a semi-structured form was used. The first part of the form was about the participants' demographic information. In the second part, participants were asked to fill in sentences as following:

"To me, Phd education is like. becuase.

"To me, instructors in the program are like.. becuase..

The study group consisted of 63 students who are actively attending their Phd education. They are from different universities and programs. The group was determined by criterion sampling which is one of purposive sampling methods. 32 of them were male and 31 of them were female.

The analysis of data was carried out as a three steps process. In the first step the data was prepared for the analysis, in the second step the data was examined and in the last one the data was deducted which is the ultimate aim of this analysis. In the first step metaphors and the reasons put forward for metaphors were written on the tables. In the second step, metaphors and their reasons were examined carefully and the ones which are not metaphors were not included. Also, if there was an inconsistency between metaphors and reasons, they were excluded. In the last step, content analysis was utilized to categorize the metaphors based on their reasons.

In the scope of the validity data was dealt in detail, the process was explained step by step and direct quotations were given. On the other hand, to ensure the reliability consensus was sought between the researchers. According to this, the consensus between the researchers was higher than $70 \%$ which is an indication of reliability. 
Participants uttered 56 metaphors for Phd education and 52 of them were different. Seven of the participants did not utter a metaphor or the expression was not a metaphor. 'sun $(f=2)$ ', 'tunnel $(f=2)^{\prime}$ ', 'stair $(f=2)$ ' and 'tunnel $(f=2)$ ' were the metaphors which were repeated. All the other metaphors were used only once. These 56 metaphors were categorized as positive, negative and neutral. There were 29 metaphors in the positive category $(51,7 \%) ; 25$ metaphors in the negative category (44,6 \%) and 2 metaphors (3,7 \%) in neutral category.

Participants uttered 58 metaphors for instructors and 43 of them were different. Five of the participants did not utter a metaphor or the expression was not a metaphor. 'guide $(f=6)^{\prime}$ ', 'friend $(f=4)^{\prime}$, 'compass $(f=3)^{\prime}$, 'lantern $(f=3)^{\prime}$, 'sun $(f=2)$ ', 'polar star $(f=2)^{\prime}$ and 'master $(f=2)$ ' were the metaphors which were repeated by the participants. These 58 metaphors were categorized as positive, negative, bilateral and neutral. 38 of the metaphors uttered for instructors reflected positive perceptions ( $67 \%), 12$ of them reflected negative perceptions $(20,6 \%)$, seven of them were bilateral $(12 \%)$ and one of them reflected neutral perceptions.

To sum up, nearly half of the participants have negative perceptions of Phd education. On the other hand, most of them have positive perceptions of their instructor. In other words, participants have more positive perceptions of their instructors than the education process itself. 